\title{
NILAI KECERNAAN BAHAN KERING DAN BAHAN ORGANIK IN VITRO LITTER FERMENTASI PADA LAMA PERAM YANG BERBEDA
}

\section{DIGESTABILITY VALUE OF DRY MATERIALS AND ORGANIC MATERIALS IN VITRO LITTER FERMENTATION AT DIFFERENT PERAM TIMES}

\author{
M. Christiyanto ${ }^{1}$, B. I. M. Tampoebolon ${ }^{1}$, C. S. Utama ${ }^{1}$ dan O. S. Nugroho ${ }^{2}$ \\ ${ }^{1}$ Departemen Peternakan, Fakultas Peternakan dan Pertanian, Universitas Diponegoro \\ ${ }^{2}$ Jurusan S1 Peternakan, Fakultas Peternakan dan Pertanian, Universitas Diponegoro \\ J1. Prof. Soedarto No.13, Tembalang, Kec. Tembalang, Kota Semarang, Jawa Tengah 50275. \\ aKorespondensi:Marry Christiyanto, E-mail: marrychristiyanto@gmail.com
}

(Diterima oleh Dewan Redaksi: 26 April 2021)

(Dipublikasikan oleh Dewan Redaksi: 31 oktober 2021)

\begin{abstract}
This research was conducted to evaluate the effect of fermentation time on the in vitro dry matter digestibility (IVDMD) and in vitro organic matter digestibility (IVOMD) of fermented broiler litter as ruminant feed. The litter samples used came from 16 cages that were fermented and conducted in vitro digestibility tests. The trial design used is a complete randomized design with 4 treatment and 4 replication. The treatment were T0: time of fermentation 0 weeks; T1: time of fermentation 3 weeks; T2: time of fermentation 6 weeks and T3: time of fermentation 9 weeks. The data in the variety analysis that has been obtained is then tested with duncan test with a signification rate of $5 \%$. The results of the study found that long rippening litter broiler fermented chicken affects the IVDMD, but has no effect on the IVOMD. The recommended treatment is the length of littering of fermented broiler chickens for 6 weeks, as it provides the most optimal IVDMD value.
\end{abstract}

Keywords: litter, broiler, time of fermentation, IVDMD, IVOMD

\begin{abstract}
ABSTRAK
Penelitian bertujuan mengkaji pengaruh lama peram terhadap nilai kecernaan bahan kering (KcBK) dan kecernaan bahan organik (KcBO) litter broiler fermentasi sebagai pakan ruminansia. Sampel litter yang digunakan berasal dari 16 kandang yang kemudian difermentasi dan dilakukan uji kecernaan secara in vitro. Rancangan percobaan yang digunakan adalah rancangan acak lengkap (RAL) dengan 4 perlakukan dan 4 ulangan. Perlakuan yang diterapkan meliputi T0: litter fermentasi lama peram 0 minggu, T1: litter fermentasi lama peram 3 minggu, T2: litter fermentasi lama peram 6 minggu, dan T3: litter fermentasi lama peram 9 minggu. Parameter yang diukur dalam penelitian adalah nilai KcBK dan nilai KcBO. Data di analisis ragam dengan taraf signifikasi 5\%, dan dilanjutkan dengan uji Duncan. Hasil penelitian diketahui bahwa lama peram litter ayam broiler fermentasi berpengaruh terhadap nilai kecernaan bahan kering (KcBK), namun tidak berpengaruh terhadap nilai kecernaan bahan organik (KcBO). Perlakuan yang direkomendasikan adalah lama pemeraman litter ayam broiler fermentasi selama 6 minggu, karena memberikan nilai KcBK yang paling optimal.
\end{abstract}

Kata kunci : litter, in vitro, lama peram, KcBK, KcBO.

Marry Christiyanto, Baginda Iskandar Muda Tampoebolon, Cahya Setya Utama, S Nugroho. 2021. Nilai Kecernaan Bahan Kering Dan Bahan Organik In Vitro Litter Fermentasi Pada Lama Peram Yang Berbeda.. Jurnal Peternakan Nusantara 7(2): 59-66 


\section{PENDAHULUAN}

Peternakan ayam broiler merupakan industri yang dalam proses produksinya selain menghasilkan daging dan telur sebagai produk utama, juga menghasilkan hasil samping berupa limbah. Limbah peternakan ayam broiler terdiri atas litter dan kotoran (manure). Litter merupakan alas kandang unggas yang berguna untuk menyerap air, amonia, mengisolasi panas, dan mengurangi ayam kontak langsung dengan lantai (Najibulloh et al., 2020). Litter sebagai alas kandang berasal dari bahan seperti sekam padi, serutan kayu dan jerami padi (Saputra et al., 2015). Litter ayam broiler tersebut dapat menyebabkan dampak yang tidak baik pada lingkungan jika tidak dilakukan penanganan, karena dapat menyebabkan polusi karena memberikan bau busuk, amonia dan mikroorganisme udara seperti mikroba, mikotoksin dan endoparasit (Ma et al., 2019). Peternakan unggas menjadi salah satu penyebab terjadinya efek rumah kaca di dunia sebesar 18\% (Pravangasta et al., 2018).

Litter ayam broiler memiliki kandungan nutrien yang tinggi, umumnya diolah menjadi pupuk organik untuk meningkatkan zat hara yang ada dalam tanah (Solaiman et al., 2020). Namun bila dilakukan pengolahan lebih lanjut, litter berpotensi untuk digunakan sebagai bahan pakan ruminansia. Hal ini karena kandungan nutrien yang terkandung dalam litter ayam broiler sangat potensial untuk pakan ruminansia. Kandungan nutrien litter broiler yaitu protein kasar (PK) 25 - 50\%, total digestible nutrients (TDN) 55 - 60\% (Rahimi et al, 2018). Upaya yang dapat dilakukan agar litter dapat dimanfaatkan sebagai pakan ruminansia dan tidak menyebabkan masalah adalah dengan memanfaatkan teknologi fermentasi.

Fermentasi merupakan suatu pengolahan bahan dengan bantuan mikroorganisme, yang dilakukan untuk meningkatkan kualitas litter sehingga komponen kompleks penyusun litter dipecah menjadi lebih sederhana (Wirajata et al., 2016). Fermentasi yang dilakukan juga dapat menekan pertumbuhan mikroorganisme patogen dalam litter dan manure (Hau dan Rahyati, 2017). Fermentasi litter dapat mengurangi total bakteri patogen yang dapat mengganggu kesehatan ternak jika digunakan untuk pakan (Najibulloh et al., 2020). Jumlah bakteri asam laktat yang semakin tinggi dalam proses fermentasi dapat meningkatkan kandungan protein litter ayam. Saat proses fermentasi, mikroorganisme akan mensintetis protein melalui proses pengkayaan protein (protein encrichement) serta enzim yang dihasilkan mikroorganisme akan mendegradasi senyawa komplek menjadi senyawa yang lebih sederhana (Anggorowati et al., 2012). Fermentasi dapat menurunkan kadar serat kasar dan memperbaiki mutu dari aspek kandungan nutrisi dan daya cerna bahan karena adanya aktivitas mikroorganisme selama fermentasi (Jaelani et al., 2015). Terjadinya penurunan komposisi serat akibat fermentasi dalam bahan pakan, dapat meningkatkan nilai kecernaan bahan pakan tersebut.

Kecernaan pakan merupakan indikator yang penting sebagai petunjuk menentukan jumlah nutrien pakan yang mampu diserap oleh saluran pencernaan (Mayulu et al., 2018). Uji kecernaan in vitro dilakukan untuk menguji seberapa banyak nutrien yang dapat dicerna baik oleh mikroba rumen tanpa menggunakan ternak secara langsung (Saputro et al., 2019). Uji in vitro merupakan suatu metode uji pada media buatan yang sesuai dengan lingkungan hidupnya (Ikrom et al, 2014). Kecernaan yang tinggi menandakan semakin tinggi pula peluang nutrisi yang dapat dimanfaatkan ternak (Suardin et al., 2014). Kecernaan bahan kering (KcBK) dan kecernaan bahan organik (KcBO) dari suatu bahan, dapat menjadi penentu efisien atau tidaknya bahan pakan tersebut dapat dicerna oleh ternak.

Penelitian bertujuan untuk mengkaji pengaruh lama pemeraman terhadap nilai kecernaan bahan kering (KcBK) dan kecernaan bahan organik (KcBO) litter ayam broiler fermentasi. Penelitian bermanfaat memperoleh informasi pengaruh lama pemeraman yang berbeda terhadap nilai KcBK dan KcBO litter ayam fermentasi. Hasil penelitian dapat menjadi informasi (acuan) bagi peneliti selanjutnya dan bagi peternak dalam pengolahan litter ayam broiler, sehingga dapat mengurangi dampak kerusakan lingkungan yang dihasilkan.

\section{MATERI DAN METODE}

Materi yang digunakan pada penelitian adalah litter ayam broiler yang telah dilakukan fermentasi selama 0, 3, 6 dan 9 minggu. Alat yang digunakan dalam penelitian antara lain timbangan analitik ketelitian 0,001, cawan porselen, oven, tanur, erlenmeyer, deksikator, tabung fermentor in vitro berventilasi, gunting, pompa vacum, kertas Whatman No. 41, 
sentrifuse, dan inkubator. Bahan yang digunakan dalam penelitian antara lain litter ayam broiler, cairan rumen sapi potong, aquades, aseton, larutan $\mathrm{H}_{2} \mathrm{SO}_{4}$, larutan $\mathrm{NaOH}$, larutan McDougall, larutan pepsin $\mathrm{HCl}$, bakteri mix culture untuk fermentasi dan substrat fermentasi yang terdiri atas molases, garam, mineral mix dan urea. Metode penelitian yang dilakukan terdiri atas beberapa bagian antara lain, rancangan penelitian, tahap fermentasi, tahap in vitro dan pengambilan data, serta tahap analisis data.

\section{Rancangan Penelitian}

Penelitian ini menggunakan Rancangan Acak Lengkap (RAL) dengan 4 perlakuan dan 4 ulangan, sehingga terdapat 16 unit percobaan. Perlakuan yang diberikan adalah sebagai berikut.

T0 : Litter fermentasi lama peram 0 minggu (0 hari/ tanpa fermentasi)

T1 : Litter fermentasi lama peram 3 minggu (21 hari)

T2 : Litter fermentasi lama peram 6 minggu (42 hari)

T3 : Litter fermentasi lama peram 9 minggu (63 hari).

\section{Tahap Fermentasi}

Fermentasi litter diawali dengan mengumpulkan litter ayam broiler dari 16 kandang di daerah Kabupaten Demak, Kabupaten Kendal dan Kota Semarang. Litter yang diperoleh, ditimbang sebanyak $1 \mathrm{~kg}$ dan selanjutnya ditambahkan 60 gram starter mix culture. Substrat yang terdiri atas 60 gram mineral $m i x, 60$ gram urea, 60 gram garam, $60 \mathrm{ml}$ molases yang dicampur air $100 \mathrm{ml}$, ditambahkan ke litter. Semua bahan dicampur sampai homogen dan dimasukkan kedalam wadah plastik fermentasi yang diikat rapat. Litter selanjutnya diperam sesuai dengan perlakuan (T0, T1, T2 dan T3)

\section{Tahap In Vitro dan Pengambilan Data}

Tahap in vitro yang dilakukan sesuai dengan metode Tilley dan Terry (1963), dengan menganalisis kecernaan bahan kering (KcBK) dan kecernaan bahan organik (KcBO) litter ayam broiler. Sampel ditimbangan sebanyak 0,55-0,56 gram. Litter ayam broiler sesuai perlakuan dimasukkan kedalam rabung fermentor yang telah diisi dengan $40 \mathrm{ml}$ larutan McDougall dan10 ml cairan rumen, selanjutnya disebut sampel. Tabung fermentor dibuat dalam kondisi anaerob dengan mengalirkan gas $\mathrm{CO}_{2}$ ke dalam tabung, selanjutnya tabung ditutup dan diinkubasi. Inkubasi sampel dilakukan selama 48 jam pada suhu $39{ }^{\circ} \mathrm{C}$. Sampel dihomogenkan setiap 6 jam sekali, dengan memutar bagian bawah tabung membentuk angka delapan. Setelah 48 jam, tabung diangkat, dimasukkan ke dalam wadah berisi air es. Sampel disentrifuse pada kecepatan $3000 \mathrm{rpm}$ selama 10 menit, sehingga endapan sampel akan berpisah dengan cairan. Cairan dibuang, sementara endapan dibiarkan dalam tabung dan ditambahkan larutan pepsin $\mathrm{HCl}$ sebanyak $50 \mathrm{ml}$. Inkubasi kembali dilakukan selama 48 jam pada suhu 39 ${ }^{\circ} \mathrm{C}$, dan pengadukan setiap 6 jam sekali. Selanjutnya dilakukan penyaringan sehingga diperoleh residu. Residu dioven pada suhu 110 ${ }^{\circ} \mathrm{C}$ selama 24 jam, dan dimasukkan ke deksikator. Nilai KcBK dihitung dengan rumus perhitungan sebagai berikut :

$$
\begin{aligned}
& \text { KcBK (\%) } \\
& =\frac{\text { BK Sampel }(\mathrm{g})-(\text { BK residu }(\mathrm{g})-\text { BK Blanko }(\mathrm{g}))}{\text { BK Sampel }(\mathrm{g})} \times 100
\end{aligned}
$$

Sampel selanjutnya ditanur pada suhu $600{ }^{\circ} \mathrm{C}$ selama 6 jam, dan dilakukan perhitungan nilai KcBO dengan menggunakan rumus sebagai berikut.

$$
\begin{aligned}
& \text { KcBO (\%) } \\
& =\frac{\text { BO Sampel }(\mathrm{g})-(\text { BO residu }(\mathrm{g})-\text { BO Blanko }(\mathrm{g}))}{\text { BO Sampel }(\mathrm{g})} \times 100
\end{aligned}
$$

\section{Tahap Analisis Data}

Data yang diperoleh diuji menggunakan analisis variansi berdasarkan rancangan acak lengkap dengan membandingkan nilai $\mathrm{F}$ hitung dengan $F$ tabel pada taraf signifikasi 5\%. Perlakuan yang berpengaruh nyata dilanjutkan uji Duncan untuk mengetahui perbedaan nilai tengah antar perlakuan.

\section{HASIL DAN PEMBAHASAN}

\section{Kecernaan Bahan Kering (KcBK)}

Berdasarkan hasil penelitian pada Tabel 1 . menunjukkan bahwa terdapat pengaruh nyata $(\mathrm{P}<0,05)$ perlakuan lama pemeraman yang berbeda terhadap nilai kecernaan bahan kering (KcBK) litter ayam broiler fermentasi. 
Tabel 1. Nilai KcBK Litter Ayam Broiler Fermentasi pada Lama Peram yang Berbeda

\begin{tabular}{|c|c|c|c|c|}
\hline \multirow{2}{*}{$\begin{array}{c}\text { Ulan } \\
\text { gan }\end{array}$} & \multicolumn{4}{|c|}{ Perlakuan } \\
\hline & T0 & $\mathrm{T} 1$ & $\mathrm{~T} 2$ & $\mathrm{~T} 3$ \\
\hline & \multicolumn{4}{|c|}{----------------------------------------- \% } \\
\hline U1 & 47,720 & 52,872 & 59,221 & 53,843 \\
\hline $\mathrm{U} 2$ & 48,666 & 53,848 & 60,664 & 52,324 \\
\hline U3 & 47,904 & 53,610 & 57,878 & 52,866 \\
\hline $\mathrm{U} 4$ & 46,402 & 51,064 & 58,001 & 52,396 \\
\hline Rata & $47,673^{\mathrm{c}} \pm$ & $52,849^{\mathrm{b}} \pm$ & $58,941^{\mathrm{a}} \pm$ & $52,857^{\mathrm{b}} \pm$ \\
\hline - rata & 0,94 & 1,26 & 1,30 & 0,70 \\
\hline
\end{tabular}

Rata-rata KcBK litter ayam broiler fermentasi tertinggi ke terendah secara berurutan adalah T2 $(58,941 \%)$, T3 $(52,857 \%), \mathrm{T} 1(52,849 \%)$ dan T0 (47,673\%). Hasil penelitian menunjukkan bahwa T0 berbeda nyata dengan T1, T2, dan T3; T1 tidak berbeda nyata dengan $\mathrm{T} 3$ namun berbeda nyata dengan T2; dan T2 berbeda nyata dengan T3. Nilai KcBK yang lebih rendah pada perlakuan T0 dapat terjadi karena pada perlakuan tersebut tidak ada waktu untuk fermentasi, sehingga tidak ada mekanisme perombakan komponen litter menjadi lebih sederhana. Komponen litter yang lebih kompleks pada T0 membuat bakteri pengurai selama in vitro tidak optimal mendegradasi litter, sehingga memberikan hasil KcBK yang paling rendah. Jaelani et al. (2015) menyatakan bahwa fermentasi dapat menurunkan kadar serat kasar dan memperbaiki mutu dari aspek kandungan nutrisi dan daya cerna bahan karena adanya aktivitas mikroorganisme selama fermentasi.

Nilai KcBK pada perlakuan T1 dan T3 tidak berbeda nyata, namun nilai kedua perlakuan fermentasi tersebut lebih tinggi dari perlakuan T0 (tanpa fermentasi). Hal tersebut dapat terjadi karena aktivitas mikroorganisme selama fermentasi akan mengurai kandungan nutrisi pada litter berupa serat kasar seperti selulosa, hemiselulosa, dan lignin, sehingga kecernaan bahan pada perlakuan tersebut menjadi lebih baik. Suningsih et al. (2019) menyatakan bahwa perubahan fraksi serat terjadi karena adanya proses hidrolisis dari mikroorganisme yang melarutkan silika dan lignin, serta mendegradasi ikatan lignohemiselulosa dengan lignoselulosa yang terdapat pada dinding sel bahan. Semakin lama pemeraman, maka semakin lama waktu fermentasi dan mengakibatkan populasi bakteri asam laktat akan semakin tinggi dalam mendegradasi berbagai jenis gula yang terkandung dalam litter ayam broiler. Ferdaus et al. (2008) menyatakan bahwa waktu fermentasi yang semakin bertambah, dapat mengakibatkan pertumbuhan dan perkembangan bakteri asam laktat semakin tinggi.

Nilai KcBK pada perlakuan T2 memberikan hasil paling tinggi dapat terjadi diduga kerena waktu tersebut paling optimal untuk bakteri fermentasi menyederhanakan komponen penyusun litter. Nilai tersebut masih lebih rendah dari hasil penelitian yang telah dilakukan oleh Alam et al. (2008) yang menyatakan bahwa pakan yang diberi litter broiler memiliki nilai KcBK sekitar 61,07\%, serta hasil penelitian $\mathrm{Al}$ Galbi (2013) yang menyatakan bahwa nilai KcBK untuk pakan dengan pemberian eksreta broiler adalah sebesar $61,39-65,56 \%$. Fermentasi yang dilakukan dapat meningkatkan nilai KcBK litter ayam broiler. Nilai KcBK cenderung meningkat sejalan dengan lama fermentasi sampai 6 minggu, namun terjadi penurunan nilai KcBK pada lama fermentasi 9 minggu. Hal tersebut dimungkinkan disebabkan oleh mikroba yang telah memaksimalkan pemecahan substrat litter broiler sampai minggu 6 minggu, sehingga substrat yang dapat digunakan oleh mikroba juga berkurang. Hariyani dan Chuzaemi (2019) menyatakan bahwa semakin lama waktu fermentasi jumlah substrat yang mampu difermentasi oleh mikroba juga berkurang.

Nilai KcBK yang semakin tinggi pada perlakuan T2 menandakan semakin banyak bahan kering yang tercerna oleh mikroba. Semakin banyak bahan kering pakan yang dicerna dalam saluran pecernaan, maka semakin efisien bahan pakan tersebut yang dapat dimanfaatkan untuk pertumbuhan dan perkembangan ternak. Fermentasi selama 6 minggu memberikan hasil KcBK terbaik. Adli et al. (2017) menyatakan bahwa fermentasi dapat menyebabkan banyak nutrien tercerna dan mengurangi bahan kering yang selanjutnya menghasilkan asam laktat dan air karena adanya pencernaan gula sederhana. Pengolahan fermentasi litter meningkatkan nilai KcBK litter karena frkasi serat penyusun litter menjadi lebih sederhana, sehingga sangat direkomendasikan dilakukan sebelum litter diberikan kepada ternak. Hartono et al. (2015) menyatakan bahwa fermentasi dapat memecah ikatan lignin dengan serat kasar seperti selulosa dan hemiselulosa.

\section{Kecernaan Bahan Organik (KcBO)}

Berdasarkan hasil penelitian pada Tabel 2 . menunjukkan bahwa tidak terdapat pengaruh nyata $(\mathrm{P}<0,05)$ perlakuan lama pemeraman yang 
berbeda terhadap nilai kecernaan bahan organik (KcBO) litter ayam broiler fermentasi.

Tabel 2. Nilai KcBO Litter Ayam Broiler Fermentasi pada Lama Peram yang Berbeda

\begin{tabular}{|c|c|c|c|c|}
\hline \multirow{2}{*}{$\begin{array}{c}\text { Ulang } \\
\text { an }\end{array}$} & \multicolumn{4}{|c|}{ Perlakuan } \\
\hline & T0 & $\mathrm{T} 1$ & $\mathrm{~T} 2$ & $\mathrm{~T} 3$ \\
\hline & ---------- & ----- & 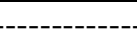 & ---- \\
\hline U1 & 77,774 & 75,183 & 77,909 & 73,219 \\
\hline $\mathrm{U} 2$ & 74,572 & 76,052 & 77,118 & 75,330 \\
\hline U3 & 77,288 & 78,542 & 75,402 & 73,010 \\
\hline $\mathrm{U} 4$ & 77,714 & 75,115 & 74,364 & 74,170 \\
\hline Rata - & $76,837 \pm$ & $76,223 \pm$ & $76,198 \pm$ & $73,932 \pm$ \\
\hline rata & 1,53 & 1,60 & 1,61 & 1,06 \\
\hline
\end{tabular}

Rata-rata KcBO litter ayam broiler adalah T0 (76,837\%), T1 (76,223\%), T2 (76,198\%) dan T3 $(73,936 \%)$. Hasil penelitian menunjukkan bahwa perlakuan lama pemeraman pada perlakuan T0, T1, T2 dan T3 tidak mempengaruhi nilai KcBO litter ayam fermentasi. Tidak adanya perbedaan tersebut diduga terjadi karena kandungan abu pada litter tidak dapat didekomposisi oleh bakteri selama fermentasi. Hal tersebut mengakibatkan kandungan abu pada setiap perlakuan relatif sama, sehingga memberikan nilai KcBO yang hampir sama pula. Yuliarto et al. (2015) menyatakan bahwa kecernaan bahan organik erat kaitannya dengan kandungan abu (bahan anorganik), semakin tinggi kandungan abu, maka semakin rendah kecernaan bahan organik. Kandungan mineral/ abu yang ada di litter meskipun tidak dapat dicerna bakteri fermentasi, namun kadar tersebut masih tergolong rendah, sehingga memberikan hasil nilai KcBO yang tinggi pada penelitian ini. Suadnyana et al. (2019) menyatakan bahwa kadar abu yang terkandung dalam suatu bahan tidak dipengaruhi oleh proses fermentasi.

Nilai KcBO pada penelitian ini hampir sama dengan yang dilaporkan oleh Flachowsky dan Hennig (1990) yang menyatakan bahwa nilai KcBO litter broiler adalah $50-73 \%$, dan hasil penelitian Shahowna et al. (2013) bahwa nilai KcBO litter yang ditambahkan ke pakan adalah berkisar antara 67,35 - 79,79\%. Namun, hasil dalam penelitian ini lebih tinggi dari yang dilaporkan oleh Lanyasunya et al. (2006) yang menyatakan bahwa KcBO litter ayam sebesar 60 - 65\%. Nilai KcBO ini menunjukkan kemampuan bahan pakan untuk dicerna dalam sistem pencernaan. Setiyaningsih et al. (2012) menyatakan bahwa nilai KcBO suatu bahan pakan dipengaruhi oleh kandungan pada pakan, terutama kandungan serat kasar.

Meskipun lama pemeraman tidak memberikan hasil yang berbeda nyata, namun nilai KcBO pada penelitian ini lebih tinggi daripada nilai KcBK pada semua perlakuan. Hal tersebut dapat terjadi karena pada pengukuran KcBK masih terdapat abu dari litter, sedangkan pada KcBO sudah tidak ada. Dewi et al. (2020) menyatakan bahwa nilai KcBK dapat lebih rendah dari pada nilai KcBO dapat terjadi karena pada KcBK terdapat abu yang dapat menghambat kecernaan bahan. Selain faktor kandungan abu, KcBO juga dipengaruhi oleh kandungan serat dalam litter ayam broiler fermentasi. Dwi et al. (2021) menyatakan bahwa kandungan serat kasar dan mineral adalah faktor yang dapat mempengaruhi kecernaan bahan organik suatu bahan.

\section{KESIMPULAN DAN IMPLIKASI}

Berdasarkan penelitian yang telah dilakukan dapat disimpulkan bahwa lama peram litter ayam broiler fermentasi berpengaruh terhadap nilai kecernaan bahan kering (KcBK), namun tidak berpengaruh terhadap nilai kecernaan bahan organik (KcBO). Perlakuan yang direkomendasikan adalah lama pemeraman litter ayam broiler fermentasi selama 6 minggu, karena memberikan nilai KcBK yang paling optimal.

\section{Ucapan Terima Kasih}

Ucapan terima kasih kepada Lembaga Penelitian dan Pengabdian kepada Masyarakat atas fasilitasinya dalam penugasan kegiatan Penelitian Dasar Direktorat Riset dan Pengabdian Masyarakat Direktorat Jenderal Riset dan Pengembangan Kementerian Riset, Teknologi, dan Pendidikan Tinggi dengan Nomor: 225-67/UN7.6.1/PP/2020 tanggal 20 Maret 2020.

\section{DAFTAR PUSTAKA}

Adli DN, Sjofjan O, Mashudi. 2017. A study: dried of poultry waste urea-molasses block (dpw$\mathrm{umb}$ ) as potential for feed supplementation. Jurnal Agripet 17: 144 - 149.

Alam MS, khan MJ, Akbar MA, Kamruzzaman M. 2008. Broiler litter and layer manure in the diet of growing bull calves. The Bangladesh Veterinarian 25: 62-67. 
Al-Galbi HJ. 2013. Utilization of diet containing poultry excreta by cattle and buffalo rumen microorganisms in vitro. Basrah Journal of Veterinary Research 12: 296-308.

Anggorowati DA, Setyawati H, Purba ABP. 2017. Peningkatan kandungan protein abon nangka muda. Jurnal Teknik Kimia 7: 17-21.

Dewi O, Suryani NN, Mudita IM. 2020. Kecernaan bahan kering dan bahan organik secara invitro dari silase kombinasi batang pisang dengan kembang telang (Clitoria ternatea). Journal of Tropical Animal Science 8: 60-73.

Dwi I, Definiati N. 2021. Kecernaan bahan kering dan bahan organik limbah sayuran dengan teknologi pengolahan (wafer, pellet dan fermentasi) secara in-vitro. Jurnal Inspirasi Peternakan 1: 60-71.

Ferdaus F, M O Wijayanti, E S Retnonigtyas dan W Irawati. 2008. Pengaruh ph, konsentrasi substrat, penambahan kalsium karbonat dan waktu fermentasi terhadap perolehan asam laktat dari kulit pisang. Jurnal Widya Teknik 7: 1-14.

Flachowsky G, Hennig A. 1990. Composition and digestibility of untreated and chemically treated animal excreta for ruminants a review. Biological Wastes 31: 17-36.

Hariyani 0, Chuzaemi S. 2019. Pengaruh lama fermentasi ampas putak (Corypha gebanga) terhadap produksi gas dan nilai kecernaan secara in vitro menggunakan Aspergillus oryzae. Jurnal Nutrisi Ternak Tropis 2: 53-62.

Hartono R, Y Fenita, Sulistyowati E. 2015. Uji in vitro kecernaan bahan kering, bahan organik dan produksi n-nh3 pada kulit buah durian (Durio zibethinus) yang difermentasi jamur tiram putih (Pleurotus ostreatus) dengan perbedaan waktu inkubasi. Jurnal Sain Peternakan Indonesia 10: 87-94.

Hau EER, Rohyati E. 2017. Aktivitas antibakteri nira lontar terfermentesi dengan variasi lama waktu fermentasi terhadap bakteri gram positif (Staphylococcus aureus) dan gram negatif (Escherichia coli).Jurnal Kajian Veteriner 5: 91-98.

Ikrom, Asih TRD, Wira R, Perkasa B, Tiara R Wasito. 2014. Studi in vitro ekstrak etanol daun kamboja (Plumeria alba) sebagai anti Aeromonas hydrophila. Jurnal Sain Veteriner 32: 105-116.

Jaelani A, Widaningsih N, Mindarto E. 2015. Pengaruh lama penyimpanan hasil fermentasi pelepah sawit oleh Trichoderma sp terhadap derajat keasaman $(\mathrm{pH})$, kandungan protein kasar dan serat kasar. Ziraa'ah Majalah Ilmiah Pertanian 40: 232-240.

Lanyasunya TP, Rong WH, Abdulrazak SA, Kaburu PK, Makori JO, Onyango TA, Mwangi DM. 2006. Factors limiting use of poultry manure as protein suplement dairy cattle on smallholder farm in Kenya. International Journal Poultry Science 5: 75-80.

Ma Q, K P Paudel, D Bhandari, C Theegala M Cisneros. 2019. Implications of poultry litter usage for electricity production. Waste Management 95: 493-503.

Mayulu H, N Fauziah, M Christiyanto, S Sunarso ,Haris M. 2018. Digestibility value and fermentation level of local feed-based ration for sheep. Animal Production 20: 95-102.

Najibulloh M, N Ulupi, Salundik. 2020. Pengaruh daur ulang litter terhadap kualitas litter dan udara dalam pemeliharaan broiler. Livestock Animal. Research 18: 107-115.

Pravangasta A S, M H H Ichsan, Maulana R. 2018. Sistem monitoring kadar gas berbahaya berdasarkan amonia dan metana pada peternakan ayam broiler menggunakan protokol mqtt pada realtime system. Jurnal Pengembangan Teknologi Informasi dan Ilmu Komputer 2: 4056-4063.

Rahimi M R, Y A Alijoo, R Pirmohammadi , Alimirzaei M. 2018. Effects offeeding with broiler litter in pellet-form diet on Qizil fattening lambs' performance, nutrient digestibility, blood metabolites and husbandry economics. Veterinary Reserch Forum 9: 245-251.

Saputra I K, A S Trisnadewi dan I G Cakra. 2019. Kecernaan in vitro dan produk fermentasi dari silase jerami padi yang dibuat dengan penambahan cairan rumen. Jurnal Peternakan Tropika 7: 647-660.

Saputra T H, K Nova dan D Septinova. 2015. Pengaruh penggunaan berbagai jenis litter 
terhadap bobot hidup, karkas, giblet, dan lemak abdominal broiler fase finisher di closed house. Jurnal Ilmiah Peternakan Terpadu 3: 38-44.

Setiyaningsih K D, M Christiyanto dan Sutarno. 2012. Kecernaan bahan kering dan bahan organik secara in vtro hijauan Desmodium cinereum pada berbagai dosis pupuk organik cair dan jarak tanam. Animal Agricultural Journal 1: 51 - 63 .

Shahowna,E.M., A.G. Mahala, A.M. Mokhtar, E.O. Amasaibn and B. Attaelmnan. 2013. Evaluation of nutritive value of sugar cane bagasse fermented with poultry litter as animal feed. African Journal of Food Science and Technology 4: 44-47.

Solaiman Z M, M I Shafi, E Beamont dan H M Anawar. 2020. Poultry litter biochar increases mycorrhizal colonisation, soil fertility and cucumber yield in a fertigation system on sandy soil. Agriculture 10:1-14.

Suadnyana I M, I G L O Cakra dan I W Wirawan. 2019. Kualitas fisik dan kimia silase jerami padi yang dibuat dengan penambahan cairan rumen sapi bali. Journal of Tropical Animal Science 7: 661-675.

Suardin N, Sandiah dan R Aka. 2014. Kecernaan bahan kering dan bahan organik campuran rumput mulato (Brachiaria hybrid.cv.Mulato) dengan jenis legum berbeda menggunakan cairan rumen sapi. Jurnal Ilmu dan Teknologi Peternakan Tropis 1: 16-22.

Suningsih N, W Ibrahim, O Liandris, dan R Yulianti 2019. Kualitas fisik dan nutrisi jerami padi fermentasi pada berbagai penambahan starter. Jurnal Sain Peternakan Indonesia 14: 191-200.

Tilley J M dan R A Terry. 1963. A two stage technique for in vitro digestion of forage crops. J. Br. Grassland Soc 18: 104-111.

Wirajaya K A, G P G Putra dan N S Antara. 2016. Pengaruh lama fermentasi secara anaerob cairan pulpa hasil samping fermentasi biji kakao terhadap karakteristik alkohol. Jurnal Rekayasa dan Manajemen Agroindustri 4: 8291.

Yuliarto B G, B Ayuningsih dan A Rochana. 2015. Kecernaan bahan kering dan bahan organik (in vitro) batang pisang (Musa paradisiaca) produk ensilase dengan penambahan sumber nitrogen dan sulfur sebagai pakan sapi. Students e-Journal 4: 1-15. 
